\title{
Value of the Glasgow coma scale, age, and arterial blood pressure score for predicting the mortality of major trauma patients presenting to the emergency department
}

\author{
Erhan Ahun, M.D., ${ }^{1}$ Özlem Köksal, M.D., ${ }^{1}$ Deniz Sığırlı, M.D., ${ }^{2}$ \\ Gökhan Torun, M.D., ${ }^{1}$ Serdar Suha Dönmez, M.D., ${ }^{1}$ Erol Armağan, M.D. ${ }^{1}$
}

${ }^{1}$ Department of Emergency Medicine, Uludag University Faculty of Medicine, Bursa;

${ }^{2}$ Department of Biostatistics, Uludag University Faculty of Medicine, Bursa

\begin{abstract}
BACKGROUND: The purpose of this study is to detect the mortality predictive power of new Glasgow coma scale, age, and arterial pressure (GAP) scoring system in major trauma patients admitted to the emergency department (ED).

METHODS: A total of 100 major trauma patients admitted to Uludağ University Faculty of Medicine ED who were I8 years of age or more were included in the study. In this prospective study, revised trauma score (RTS), injury severity score (ISS), trauma-related ISS (TRISS), Mechanism, GAP (MGAP) and GAP scores of the patients were calculated.

RESULTS: A significant positive correlation was established between ISS, TRISS, MGAP, and GAP in predicting in-hospital mortality $(\mathrm{p}<0.000 \mathrm{I})$. Short-term (24 hours) and long-term (4-week) mortality prediction rates and area under the curve in receiver operating characteristics analysis were $0.727-0.680$ for RTS, $0.863-0.816$ for ISS, $0.945-0,91$ I for TRISS, $0.970-0.938$ for MGAP, and 0.910-0.904 for GAP. All calculated trauma scoring systems revealed a significant mortality prediction power $(p<0.00 \mathrm{I})$. GAP score was found statistically and significantly selective and sensitive in predicting both in-ED and in-hospital mortality $(p=0.000 \mathrm{I})$.
\end{abstract}

CONCLUSION: In major trauma patients, GAP score is an easily calculable system both in the field and at the time of admission in the EDs by providing emergency physicians with future decision-making schemes by means of mortality prediction of the patients.

Key words: Major trauma; mortality; trauma scoring systems.

\section{INTRODUCTION}

Trauma is a serious problem worldwide, particularly affecting the young. Accordingly, trauma results in production loss in addition to being a health problem. It is also the leading cause of death in people from I to 44 years of age, while it is in the third leading cause for all age groups, following cancer and

Address for correspondence: Özlem Köksal, M.D.

Uludă̆ Üniversitesi Tıp Fakültesi, Acil Tıp Anabilim Dalı,

Görükle Yerleşkesi, 16059 Bursa, Turkey

Tel: +90 224 - 2953222 E-mail: koksalozlem@gmail.com

Qucik Response Code Ulus Travma Acil Cerrahi Derg

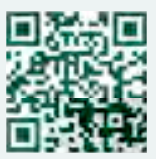

20।4;20(4):24I-247

doi: $10.5505 /$ tjtes.20I4.76399

Copyright 2014

TJTES cardiovascular diseases. ${ }^{[1]}$ Previous studies have demonstrated that $25-50 \%$ of deaths due to trauma are preventable. ${ }^{[2]}$ Trauma scoring systems (TSSs) have been used for nearly four decades to determine the type and severity of trauma and predict the prognosis of trauma patients with an increased mortality rate. ${ }^{[3]}$

The practical use of some current TSSs is somewhat restricted in terms of calculation difficulty and the requirement of laboratory data for scoring. The Glasgow coma scale (GCS)age-systolic blood pressure (SBP) (GAP) score is a physiological trauma scoring system defined in a study by Kondo et al. $^{[4]}$ It is remarkable due to the requirement of fewer parameters, its applicability in the field, and mortality predictive power very similar to the trauma-related injury severity score (TRISS). ${ }^{[4]}$ The GAP score is easily calculable both in the field and at the time of admission to the emergency department (ED). 
The purpose of this study was to detect the mortality predictive power of a new GAP scoring system for major trauma patients admitted to the ED. We therefore compared the revised trauma score (RTS), the ISS, TRISS, and the mechanism, GAP (MGAP) scores.

\section{MATERIALS AND METHODS}

Following a physical examination, a total of 100 major trauma patients admitted to the Uludag University Faculty of Medicine ED who were 18 years of age or older were included in the study (Ethic Board number: 2012-13/9). Pregnant patients and those with psychiatric illnesses were excluded. Demographic data (age, gender), type of arrival, GCS, blood pressure, oxygen saturation, respiration rate, injury mechanism, vital signs, anatomic sites of injury, alcohol intake, prescribed treatments, required consultations, final outcome (hospitalization, transfer, discharge, treatment rejection, and exitus), and unit of hospitalization (clinic, intensive care unit [ICU]) were recorded.

Using the phone numbers and addresses recorded at the time of admission, the patients were contacted and followed up during a 4-week period to calculate the short-term (24 hours) and long-term (4-week) mortality prediction rates. The RTS, ISS, TRISS, MGAP, and GAP scores were calculated by evaluating the patient data, laboratory data, and radiologic imaging and consultation results recorded in the data processing system. The prediction of mortality by TSS was classified as low risk ( $<5 \%)$, intermediate risk (5-50\%) and high risk (>50\%). The patient RTS, ISS, and TRISS were obtained using a score calculator available at www.trauma.org. For the MGAP and GAP scores, the point scoring systems reported by Sartorius et al. ${ }^{[5]}$ and Kondo et al. were used, respectively ${ }^{[4]}$ (Table I).

Statistical analyses were performed with IBM SPSS Statistics 21.0 and MedCalc 12.2.1.0. Normality of the variables was tested with the Shapiro-Wilk test. For normally distributed

Table I. GAP scoring system

\begin{tabular}{ll}
\hline GCS & \\
$3-15$ & $3-15$ points \\
Age & \\
$<60$ & 3 points \\
$>60$ & 0 point \\
Systolic blood pressure $(\mathrm{mmHg})$ & \\
$>120$ & 6 points \\
$60-120$ & 4 points \\
$<60$ & 0 point \\
\hline
\end{tabular}

GAP: Glasgow coma scale, age, and arterial pressure; GCS: Glasgow coma scale. variables mean \pm standard deviation were given as descriptive statistics; otherwise median (minimum-maximum) values were given. Mann-Whitney U-test was used to compare two independent groups. Fisher's exact test was used to compare categorical variables and $\mathrm{n}$ and percentage values were given as descriptive statistics. Receiver operating characteristics

Table 2. Characteristics of the trauma patients

\begin{tabular}{|c|c|c|c|}
\hline & $\mathbf{n}$ & $\%$ & Mean $\pm S D$ \\
\hline Age (years) & & & $40.35 \pm 16.11$ \\
\hline \multicolumn{4}{|l|}{ Gender } \\
\hline Male & 77 & 77 & \\
\hline Female & 23 & 23 & \\
\hline \multicolumn{4}{|l|}{ Arrival } \\
\hline From scene & 80 & 80 & \\
\hline By transfer & 20 & 20 & \\
\hline \multicolumn{4}{|l|}{ Type of transport } \\
\hline Ambulance & 99 & 99 & \\
\hline Private vehicle & 1 & I & \\
\hline \multicolumn{4}{|l|}{ Type of injury } \\
\hline Blunt & 98 & 98 & \\
\hline Penetrating & 2 & 2 & \\
\hline \multicolumn{4}{|l|}{ Mechanism } \\
\hline In-vehicle traffic accident & 68 & 68 & \\
\hline Extravehicular traffic accident & 6 & 6 & \\
\hline Falling from a height & 13 & 13 & \\
\hline Motorbike accident & II & II & \\
\hline Injury by firearms & 1 & 1 & \\
\hline Sharp object injuries & 1 & 1 & \\
\hline \multicolumn{4}{|l|}{ Injured area } \\
\hline Head-neck & 55 & 55 & \\
\hline Face & 19 & 19 & \\
\hline Chest & 57 & 57 & \\
\hline Abdomen & 18 & 18 & \\
\hline Extremity & 70 & 70 & \\
\hline Other & 2 & 2 & \\
\hline \multicolumn{4}{|l|}{ Vital signs } \\
\hline Pulse (per min) & & & $90.99 \pm 17.57$ \\
\hline $\mathrm{SBP}(\mathrm{mmHg})$ & & & $119.60 \pm 18.58$ \\
\hline $\mathrm{DBP}(\mathrm{mmHg})$ & & & $75.50 \pm 10.09$ \\
\hline Respiratory rate (per minute) & & & $17.19 \pm 3.22$ \\
\hline Temperature $\left({ }^{\circ} \mathrm{C}\right)$ & & & $36.25 \pm 0.36$ \\
\hline $\mathrm{SpO}_{2}$ & & & $95.57 \pm 4.78$ \\
\hline Glasgow coma score* & & & $15(3-15)$ \\
\hline Alcohol intoxication & 14 & 14 & \\
\hline
\end{tabular}

SBP: Systolic blood pressure; DBP: Diastolic blood pressure; *Data were given as median (minimum-maximum). 
(ROC) curve analysis was performed to evaluate and compare the performances of the scores. The statistical significance level was $\alpha=0.05$.

\section{RESULTS}

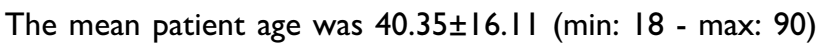
years and $77 \%$ were male. Blunt injury accounted for $98 \%$ of the injuries. The most frequent causes of presentation were in-vehicle traffic accident (68\%) and falling from a height (13\%). The most common injured body parts were the extremities (70\%), followed by the chest (57\%). Other characteristics of the trauma patients are shown in Table 2.

Of the major trauma patients, $36 \%$ were hospitalized in the ICU, and $36 \%$ were hospitalized in the clinic. The mortality rate in the ED was $3 \%$, and it was similar in the ICU and operating room (OR) within 24 hours, at $3 \%$, while the mortality rate within 4 -week was $6 \%$. The mortality rate of all patients included in the study was $12 \%$.
Trauma scoring systems (RTS, ISS, TRISS, and MGAP) were used to classify patients as having a low risk $(<5 \%)$, intermediate risk, or high risk $(>50 \%)$ of death. Two patients who were evaluated as intermediate risk by the RTS were classified as low risk by the GAP score, while I patient evaluated as low risk by the RTS was classified as intermediate risk by the GAP. In addition, I of 2 patients classified as high risk by the MGAP was classified as intermediate risk by the GAP, and 2 patients classified as low risk by the MGAP were classified as intermediate risk by the GAP. Five patients classified as intermediate risk by the GAP were reclassified as low risk by the MGAP. Five of 14 patients classified as high risk by the ISS were classified as intermediate risk by the GAP, while the GAP considered 8 of them low-risk. In addition, 20 of 24 patients classified as intermediate risk were evaluated as low risk, and 2 patients evaluated as low risk by the ISS were classified as intermediate risk. Four of 15 patients classified as intermediate risk by the TRISS were classified as low risk by the GAP. In the study by Kondo et al., patient classifications by the scoring systems were similarly reclassified by the GAP

Table 3. The comparison of GAP scores with the RTS, ISS, TRISS and MGAP score for mortality prediction groups

\begin{tabular}{|c|c|c|c|c|c|}
\hline \multirow[t]{2}{*}{ Score } & \multicolumn{5}{|c|}{ Revised trauma score } \\
\hline & Severity & $\begin{array}{l}\text { Severe } \\
\text { (<3.4 points) }\end{array}$ & $\begin{array}{l}\text { Moderate } \\
\text { ( } 3.4 \text { to } 7.2 \text { points) }\end{array}$ & $\begin{array}{l}\text { Mild } \\
\text { (>7.2 points) }\end{array}$ & Total \\
\hline \multirow[t]{4}{*}{ GAP } & Severe (3-10 points) & I & 0 & 0 & 1 \\
\hline & Moderate (II-18 points) & 0 & 10 & 1 & 11 \\
\hline & Mild (19-24 points) & 0 & 2 & 86 & 88 \\
\hline & Total & I & 12 & 87 & 100 \\
\hline \multirow[t]{2}{*}{ Score } & MGAP & & & & \\
\hline & Severity & Severe (3-I4 points) & Moderate (15-22 points) & Mild (23-29 points) & Total \\
\hline \multirow[t]{4}{*}{ GAP } & Severe (3-10 points) & 1 & 0 & 0 & 1 \\
\hline & Moderate ( $1 \mathrm{I}-18$ points) & I & 8 & 2 & II \\
\hline & Mild (19-24 points) & 0 & 5 & 83 & 88 \\
\hline & Total & 2 & 13 & 85 & 100 \\
\hline \multirow[t]{2}{*}{ Score } & ISS & & & & \\
\hline & Severity & Severe (>25 points) & Moderate (16-25 points) & Mild (<16 points) & Total \\
\hline \multirow[t]{4}{*}{ GAP } & Severe (3-10 points) & 1 & 0 & 0 & I \\
\hline & Moderate (II-I8 points) & 5 & 4 & 2 & II \\
\hline & Mild (19-24 points) & 8 & 20 & 60 & 88 \\
\hline & Total & 14 & 24 & 62 & 100 \\
\hline \multirow[t]{2}{*}{ Score } & TRISS & & & & \\
\hline & Severity & Severe (>25 points) & Moderate ( $16-25$ points) & Mild (<16 points) & Total \\
\hline \multirow[t]{4}{*}{ GAP } & Severe (3-10 points) & I & 0 & 0 & 1 \\
\hline & Moderate (II-18 points) & 0 & 11 & 0 & II \\
\hline & Mild (19-24 points) & 0 & 4 & 84 & 88 \\
\hline & Total & $\mathrm{I}$ & 15 & 84 & 100 \\
\hline
\end{tabular}

ISS: Injury severity score; GAP: Glasgow coma scale, age, and arterial pressure; TRISS: Trauma-related injury severity score; MGAP: Mechanism, Glasgow coma scale, age, and arterial pressure. 
Table 4. Characteristics of survivors versus non-survivors for 4-week mortality

\begin{tabular}{|c|c|c|c|}
\hline Characteristics & Survivors $(n=88)$ & Non-survivors $(n=12)$ & $\mathbf{p}$ \\
\hline Gender n (\%) & & & 0.286 \\
\hline Male & $66(85.7 I)$ & II (I4.29) & \\
\hline Female & $22(95.65)$ & I (4.35) & \\
\hline Age (years) & $35(18-90)$ & $52.50(18-78)$ & 0.023 \\
\hline Systolic pressure & $120(90-160)$ & $115(70-160)$ & 0.414 \\
\hline Diastolic pressure & $80(60-100)$ & $70(40-90)$ & 0.176 \\
\hline Pulse rate & $88(56-132)$ & $105(52-140)$ & 0.019 \\
\hline Respiratory rate & $16(12-25)$ & $19(9-30)$ & 0.097 \\
\hline Temperature & $36.0(36-38.2)$ & $36(36-36.7)$ & 0.722 \\
\hline $\mathrm{O}_{2}$ saturation & $97.5(83-99)$ & $92(70-99)$ & 0.008 \\
\hline Glasgow coma scale & $15(6-15)$ & $13(3-15)$ & $<0.001$ \\
\hline Revised trauma score & $7.84(5.97-7.84)$ & $7.84(3.36-7.84)$ & 0.001 \\
\hline Injury severity score & $10(1-43)$ & $24(9-48)$ & $<0.001$ \\
\hline Trauma-related injury severity score & $99.2(68.7-99.7)$ & $90(14.9-98.8)$ & $<0.001$ \\
\hline Mechanism, Glasgow coma scale, age, and arterial pressure & $27(18-29)$ & $22(15-25)$ & $<0.001$ \\
\hline Glasgow coma scale, age, and arterial pressure & $22(13-24)$ & $18(9-22)$ & $<0.001$ \\
\hline
\end{tabular}

Data are presented as $\mathrm{n}(\%)$ or median (minimum-maximum). *Mean \pm standard deviation for survivals are $7.7 \mathrm{I} \pm 0.43$ and for non-survivals are $6.49 \pm 1.82$.

score. ${ }^{[4]}$ The distribution of patients by the TSSs and their reclassification by the GAP are displayed in Table 3.

While RTS, TRISS, MGAP, and GAP values were significantly higher among 4-week survivors than among non-survivors; ISS values were significantly lower among 4-week survivors than among non-survivors. Furthermore, there was a significant difference between the survivals and non-survivals in terms of age, pulse rate, oxygen saturation, and GCS (Table 4).

ROC analyses were performed to examine the performances of RTS, ISS, TRISS, MGAP, and GAP in predicting 24-hour and 4-week mortality. The area under the curves (AUCs) were found to be 0.727 ( $p=0.012$ ) for RTS, 0.863 ( $p<0.00$ I) for ISS, $0.945(p<0.001)$ for TRISS, $0.970(p<0.00 I)$ for MGAP and $0.910(p<0.001)$ for GAP respectively, in predicting 24-hour mortality (Table 5, Fig. I).

Furthermore, AUCs were found to be $0.680(p=0.026)$ for RTS, $0.816(p<0.00 I)$ for ISS, 0.911 ( $p<0.001)$ for TRISS, $0.938(p<0.001)$ for MGAP and $0.904(p<0.001)$ for GAP respectively, in predicting 4-week mortality (Table 6, Fig. 2).

The performance of MGAP in predicting 4-week mortality was significantly higher than RTS $(p<0.00 I)$ and ISS $(p=0.039)$; but there was no significant difference between the performance of MGAP was not significantly from the GAP $(p=0.177)$ and from the TRISS $(p=0.293)$. The performance of GAP and TRISS were significantly higher from the RTS $(p<0.00 \mathrm{I}$ and $\mathrm{p}=0.001$ ).

Table 5. Predictive values of the scores in the prediction of the 24 hours mortality

\begin{tabular}{lccrrr}
\hline & Cut-off value & Sensitivity (\%) (95\% Cl) & Specificity (\%) (95\% Cl) & AUC & p \\
\hline Revised trauma score & 5.68 & $50.00(12.4-87.6)$ & $100.00(95.9-100.0)$ & 0.727 & 0.012 \\
Injury severity score & 17 & $83.33(36.1-97.2)$ & $73.86(63.4-82.7)$ & 0.863 & $<0.001$ \\
Glasgow coma scale, age, & 19 & $83.33(36.1-97.2)$ & $87.50(78.7-93.6)$ & 0.910 & $<0.001$ \\
and arterial pressure & & & & & \\
Trauma-related injury severity score & 95.4 & $100.00(54.1-100.0)$ & $87.50(78.7-93.6)$ & 0.945 & $<0.001$ \\
Mechanism, Glasgow coma scale, & 23 & $100.00(54.1-100.0)$ & $89.77(81.5-95.2)$ & 0.970 & $<0.001$ \\
age, and arterial pressure & & & & & \\
\hline
\end{tabular}

$\mathrm{Cl}$ : Confidence interval; AUC: Area under the curve. 
Table 6. Predictive values of the scores in the prediction of the 4-week mortality

\begin{tabular}{lccrrr}
\hline & Cut-off value & Sensitivity (\%) (95\% Cl) & Specificity (\%) (95\% CI) & AUC & p \\
\hline Revised trauma score & 5.97 & $41.67(15.2-72.3)$ & $95.45(88.8-98.7)$ & 0.680 & 0.026 \\
Injury severity score & 16 & $83.33(51.6-97.9)$ & $67.05(56.2-76.7)$ & 0.816 & $<0.001$ \\
Glasgow coma scale, age, and & 21 & $91.67(61.5-99.8)$ & $78.41(68.4-86.5)$ & 0.904 & $<0.001$ \\
arterial pressure & & & & & \\
Trauma-related injury severity score & 96.8 & $91.67(61.5-99.8)$ & $80.68(70.9-88.3)$ & 0.911 & $<0.001$ \\
Mechanism, Glasgow coma scale, & 25 & $100.00(73.5-100.0)$ & $80.68(70.9-88.3)$ & 0.938 & $<0.001$ \\
age, and arterial pressure & & & & & \\
\hline
\end{tabular}

$\mathrm{Cl}$ : Confidence interval; AUC: Area under the curve.

\section{DISCUSSION}

Trauma scoring systems are commonly used for prognosis and determining the severity of a patient's condition in the early stage of treatment. The TRISS is one of the most widely used TSSs, and it strongly predicts the probability of survival. [6,7] The GAP, which is one of the physiological scoring systems, is easy to use and fast to calculate and provides efficient treatment by determining the trauma severity in the early stages. This study aimed to evaluate the predictive prognostic power of the GAP scoring system for major trauma patients and its applicability in the ED by comparing it with the RTS, ISS, TRISS, and the MGAP scores.

TSSs are valuable for facilitating communication between healthcare professionals and allowing a consistent common

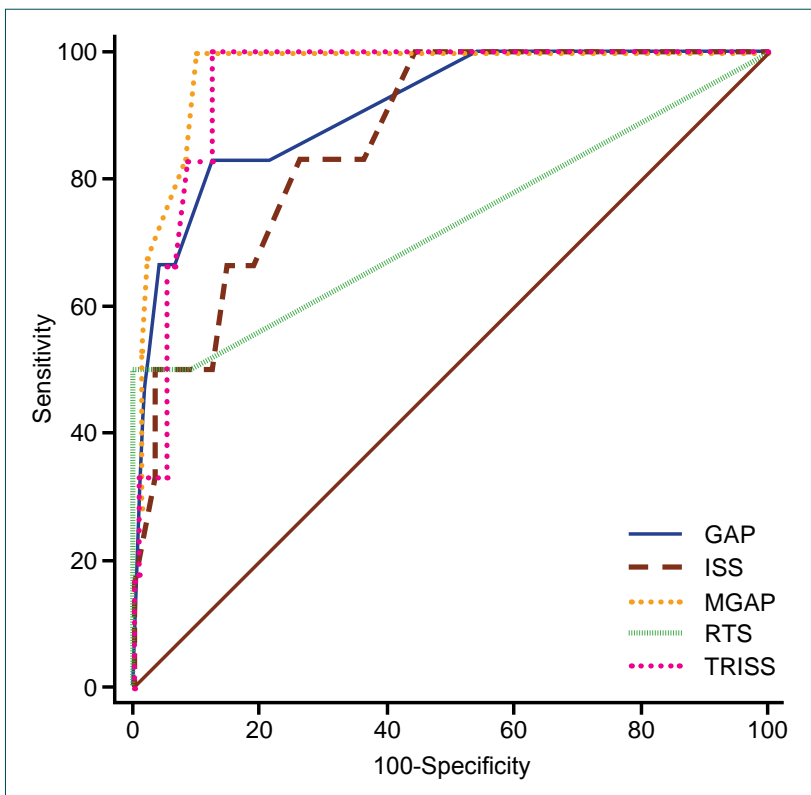

Figure 1. Receiver operating characteristics curves for the Glasgow coma scale, age, and arterial pressure (GAP), mechanism GAP, injury severity score, trauma-related injury severity score, and revised trauma score for short-term mortality prediction. language in investigations. Studies performed using similar measurements can be reliably compared. ${ }^{[8-10]}$ The literature indicates that trauma-related deaths are usually divided into three groups. Group I (50\%) includes those who die at the scene, and they are usually patients with major head trauma or severe vascular injury. Group 2 (30\%) includes those who are admitted to the hospital and die within the first several hours, a period termed the "golden hour." These injuries often include major head, thorax, and abdominal trauma. Group $3(20 \%)$ consists of patients who die at a later time, for example in an ICU. The deaths in this group are typically due to sepsis or multi-organ failure. ${ }^{\left[{ }^{\prime \prime}\right]}$ The mortality of patients in Groups 2 and 3 can be prevented through fast and accurate treatment methods. Accordingly, a TSS that is easy and efficient to use may help prevent mortality. Scoring systems are bedside methods for identifying patients with catastrophic

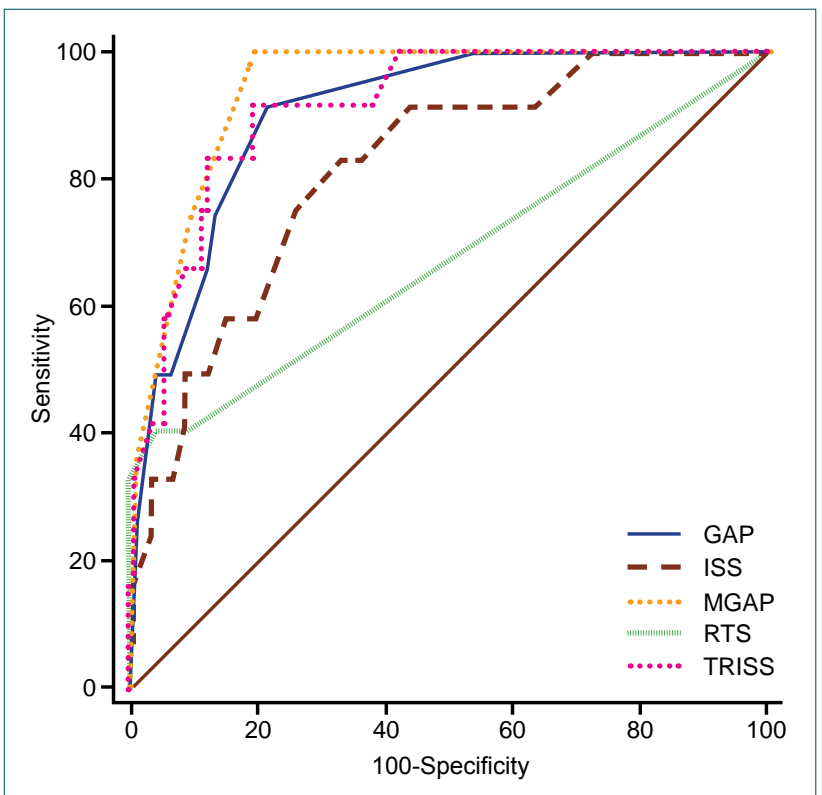

Figure 2. Receiver operating characteristics curves for the Glasgow coma scale, age, and arterial pressure (GAP), mechanism GAP, injury severity score, trauma-related injury severity score, and revised trauma score for long-term mortality prediction. 
deterioration risk by identifying abnormalities. ${ }^{[12]}$ The ISS and the TRISS are widely accepted TSSs, and their calculation requires that all examinations and workups are performed and that injuries in anatomic locations are noted in a detailed manner. The accurate determination of the seriousness of the condition on the part of patient is only possible through accurate identification of the injury. Both methods require time. It is suggested that the ISS and the TRISS should be calculated 24 hours following patient admission. ${ }^{[13]}$ Within the first several hours, termed the "golden hour," for a majority of patients presenting with major trauma, the ISS and the TRISS cannot be calculated, which handicaps their roles in guiding treatment. The prediction of prognosis is impossible at the time of ED admission using these TSSs. As the ISS and the TRISS require information not readily available at the time of presentation to the ED, they cannot provide early warning information on trauma severity for ED physicians.

Guenther et al. ${ }^{[14]}$ reported a mean in-hospital mortality rate of $26.2 \%$. The mortality rates in other studies available in the literature vary from $9 \%$ to $18.3 \% .^{[4,5,8,15]}$ Similarly, the mortality rate in our study was $12 \%$.

In the majority of trauma patients, serious injuries and mortality risk might be identified by considering physiological parameters at the scene. ${ }^{[7]}$ With this purpose, various TSSs have been developed. One of the best known is the RTS, but its adoption is limited due to the difficulty in its calculation. $[8,9,13]$ Sartorius et al. ${ }^{[5]}$ developed the MGAP score as an improvement over the previous simple trauma scores in a largescale study in France, and the predicted mortality rates were similar between the RTS and the TRISS.

We found a significant difference between the RTS and the MGAP in favor of the MGAP and between the ISS and the MGAP in favor of the MGAP; however, no significant difference was found between the GAP and the MGAP. The GAP is a physiological trauma scoring system defined by Kondo et al. in a multicenter study carried out in Japan. Patient age, GCS, and SBP are sufficient for calculating the score. Kondo et al. reported correlations in the abilities of the GAP and the RTS as well as the TRISS and the MGAP to predict mortality. While the TRISS showed better predictive results, the GAP score provided the closest predictive results to those of the TRISS. ${ }^{4]}$ In our study, the GAP score results were similar to the results of the TRISS, and no statistically significant difference was observed between them. However, a statistically significant difference was observed between the GAP and the RTS in favor of the GAP.

\section{Conclusion}

Because the GAP score is easier to calculate and has few parameters, it is advantageous for providing fast results, al- lowing quick decision making. In major trauma patients, we believe that the GAP score is an easily calculable system both in the field and at the time of admission to the ED that can suggest future decision-making schemes to ED physicians by predicting patient mortality. In addition, it is a simple scoring system that can guide healthcare staff at the scene and enable the transfer of trauma patients to trauma centers, which may reduce the loss of time.

\section{Conflict of interest: None declared.}

\section{REFERENCES}

1. Hunt RC, Krohmer JR. American College of Surgeons Committee on Trauma. Advanced Trauma Life Support Program for Doctors. 7th ed, 2004. p. 1-10.

2. Lewis FR. Initial assessment and resuscitation. Emerg Med Clin North Am 1984;2:733-48.

3. Kirkpatrick JR, Youmans RL. Trauma index. An aide in the evaluation of injury victims. J Trauma 1971;11:711-4. CrossRef

4. Kondo Y, Abe T, Kohshi K, Tokuda Y, Cook EF, Kukita I. Revised trauma scoring system to predict in-hospital mortality in the emergency department: Glasgow Coma Scale, Age, and Systolic Blood Pressure score. Crit Care 2011;15:R191. CrossRef

5. Sartorius D, Le Manach Y, David JS, Rancurel E, Smail N, Thicoïpé M, et al. Mechanism, glasgow coma scale, age, and arterial pressure (MGAP): a new simple prehospital triage score to predict mortality in trauma patients. Crit Care Med 2010;38:831-7. CrossRef

6. Llullaku SS, Hyseni NSh, Bytyçi CI, Rexhepi SK. Evaluation of trauma care using TRISS method: the role of adjusted misclassification rate and adjusted w-statistic. World J Emerg Surg 2009;4:2. CrossRef

7. Joosse P, Soedarmo S, Luitse JS, Ponsen KJ. Trauma outcome analysis of a Jakarta University Hospital using the TRISS method: validation and limitation in comparison with the major trauma outcome study. Trauma and Injury Severity Score. J Trauma 2001;51:134-40. CrossRef

8. Champion HR. Trauma scoring. Scand J Surg 2002;91:12-22.

9. Senkowski CK, McKenney MG. Trauma scoring systems: a review. J Am Coll Surg 1999;189:491-503. CrossRef

10. Hargrove J, Nguyen HB. Bench-to-bedside review: outcome predictions for critically ill patients in the emergency department. Crit Care 2005;9:376-83. CrossRef

11. Trunkey DD. Trauma. Accidental and intentional injuries account for more years of life lost in the U.S. than cancer and heart disease. Among the prescribed remedies are improved preventive efforts, speedier surgery and further research. Sci Am 1983;249:28-35. CrossRef

12. Subbe CP, Slater A, Menon D, Gemmell L. Validation of physiological scoring systems in the accident and emergency department. Emerg Med J 2006;23:841-5. CrossRef

13. Chawda MN, Hildebrand F, Pape HC, Giannoudis PV. Predicting outcome after multiple trauma: which scoring system? Injury 2004;35:34758. CrossRef

14. Guenther S, Waydhas C, Ose C, Nast-Kolb D; Multiple Trauma Task Force, German Trauma Society. Quality of multiple trauma care in 33 German and Swiss trauma centers during a 5 -year period: regular versus on-call service. J Trauma 2003;54:973-8. CrossRef

15. Champion HR, Sacco WJ, Carnazzo AJ, Copes W, Fouty WJ. Trauma score. Crit Care Med 1981;9:672-6. CrossRef 
KLINIK ÇALIŞMA - ÖZET

\section{Acil servise başvuran majör travma hastalarının mortalite tahmininde Glasgow koma skalası, yaş ve arteriyel kan basıncı skorunun değerliliği Dr. Erhan Ahun, ${ }^{1}$ Dr. Özlem Köksal, ${ }^{1}$ Dr. Deniz Sığırlı, ${ }^{2}$ Dr. Gökhan Torun, ${ }^{1}$ Dr. Serdar Suha Dönmez, ${ }^{1}$ Dr. Erol Armağan ${ }^{1}$}

${ }^{1}$ Uludağ Üniversitesi Tıp Fakültesi, Acil Tıp Anabilim Dalı, Bursa;

${ }^{2}$ Uludağ Üniversitesi Tıp Fakültesi, Biyoistatistik Anabilim Dalı, Bursa

AMAÇ: Bu çalışmanın amacı yeni bir travma skorlama sistemi olan GAP skorunun Acil Servis'e (AS) başvuran majör travma hastalarında mortalite tahmin gücünü değerlendirmektir.

GEREÇ VE YÖNTEM: Uludağ Üniversitesi Tıp Fakültesi Hastanesi AS’ye başvuran $\geq 18$ yaş majör travmalı I00 hasta çalışmaya alındı. Hasta verileri ileriye yönelik olarak değerlendirilerek hastaların RTS, ISS, TRISS, MGAP ve GAP skorları hesaplandı.

BULGULAR: Hastane içi mortaliteyi öngörmede, ISS, TRISS, MGAP ve GAP arasında pozitif yönde anlamlı bir korelasyon saptandı ( $<<0.000$ I). Travma skorlama sistemlerinin sırasıyla kısa dönem (24 saat) ve uzun dönem (4 hafta) mortalite tahmin oranları ROC analizinde Eğri Altındaki Alan (EAA)- Area Under Curve (AUC); RTS için 0.727- 0.680, ISS için 0.863-0.8I6, TRISS için 0.945-0.9II MGAP için 0.970-0.938, GAP için 0.9I00.904 olarak bulundu. Hesaplanan travma skorlarının hepsinin mortalite tahmin gücü anlamlı olarak bulundu ( $P<0.00$ I). GAP'ın hem AS'de, hem de hastane içi mortaliteyi öngörmede istatistiksel olarak anlamlı bir şekilde $(p=0.000$ I) seçici ve duyarlı olduğu belirlendi.

TARTIŞMA: Bu sonuçlarla GAP skorunun travma hastalarında, hem sahada ve hem de başvuru anında AS'de kolayca hesaplanabilecek ve hastanın mortalitesini öngörerek AS doktoruna fikir verebilecek bir skorlama sistemi olduğunu düşünmekteyiz.

Anahtar sözcükler: Majör travma; mortalite; travma skorlama sistemleri.

Ulus Travma Acil Cerrahi Derg 20।4;20(4):24I-247 doi: I0.5505/tjtes.20।4.76399 